\title{
Removal of sulphate from landfill leachate by crystallization
}

\author{
Ahmet Aygun ${ }^{1^{\dagger}}$, Selim Dogan ${ }^{2}$, Mehmet Emin Argun ${ }^{2}$, Havva Ates ${ }^{2}$ \\ ${ }^{1}$ Department of Environmental Engineering, Faculty of Engineering and Natural Sciences, Bursa Technical University, Bursa 16310, Turkey \\ ${ }^{2}$ Department of Environmental Engineering, Engineering Faculty, Selcuk University, Konya 42003, Turkey
}

\begin{abstract}
The present study explores the applicability of response surface methodology (RSM) in conjunction with central composite design (CCD) matrix to statistically optimize ettringite crystallization process for the removal of sulphate from landfill leachate. A three factor-five coded level CCD with 20 runs, was performed to estimate the best fitted model. The RSM results indicated that the fitted quadratic regression model could be appropriate to predict sulfate removal efficiency. The $\mathrm{pH}$ was identified as the most dominant parameter affecting sulphate removal. $61.6 \%$ of maximum sulphate removal efficiency was obtained at $\mathrm{pH}$ of 11.06 for a $1.87 \mathrm{O} \mathrm{Ca} / \mathrm{SO}_{4}$ and 0.51 of $\mathrm{Al} / \mathrm{SO}_{4} \mathrm{molar}$ ratios The operating cost for ettringite crystallization at optimized conditions was calculated to be $0.52 \$ / \mathrm{m}^{3}$. The significance of independent variables and their interactions were tested by analysis of variance. Scanning electron microscope (SEM) and SEM coupled with energy dispersive X-Ray spectroscopy results confirmed the formation of ettringite crystal and were used to describe its morphology features.
\end{abstract}

Keywords: Ettringite crystallization, Leachate, Response surface methodology (RSM), Scanning electron microscope (SEM), Sulphate removal

\section{Introduction}

Municipal solid waste management (MSWM) is a crucial service provided by cities all over the world, but it is often not managed well in developing countries. Improper solid waste management causes various forms of environmental pollution and health risks. Comparative studies of the various possible means of eliminating solid urban waste have revealed that the cheapest is landfilling [1]. On the other hand, generation of heavily polluted leachates having high organic and inorganic contents, presenting significant variations in both volumetric flow and its compositions in landfills are main environmental problems need to be controlled [2].

The composition of leachate greatly depends on the age of the landfill, waste type and hydrogeological factors [3]. According to the landfill age, leachate can be classified into three types: Young, middle-aged and stabilized [4]. Young landfill leachate due to its high organic content which are highly desirable for biodegradation. However, there is no unique method for leachate management to treat most of the compounds in a single step. A combination of physical (air stripping, membrane technologies), chemical (coagulation, flocculation and oxidation), biological methods (aerobic and anaerobic) and adsorption methods can be used to reach best solution [5-10].

Biological processes are low-cost method for landfill leachate,

This is an Open Access article distributed under the terms of the Creative Commons Attribution Non-Commercial License (http://creativecommons.org/licenses/by-nc/3.0/) which permits unrestricted non-commercial use, distribution, and reproduction in any medium, provided the original work is properly cited.

Copyright (C) 2019 Korean Society of Environmental Engineers when compare with the others treatment options [11]. But, inhibitory compounds such as sulphate had negative effect on anaerobic degradation of landfill leachate. High concentrations of sulphur compounds in leachate hinder wastewater treatment as a biologically and it resulted that low production of methane gas. This phenomenon results from the anaerobic reduction of sulphates into sulphides. Excess amount of sulphate will promote enhanced growth of sulphate reducing bacteria [12]. Sulphides formed during the anaerobic process inhibit the growth of methanogens in the $\mathrm{pH}$ range of 7.2-8.5 [13, 14]. Sulphate content exceeds $1 \mathrm{~g} / \mathrm{L}$ inhibition of methane production starts and total inhibition occurs when the sulphate exceeds 4.5 $\mathrm{g} / \mathrm{L}$ [15]. High ratio of $\mathrm{COD} / \mathrm{SO}_{4}$ such as 20:1 was found to be minimize inhibition effect on anaerobic methane production [16].

Ettringite is a hydrous calcium aluminum sulfate mineral with low solubility. Ettringite formation in high $\mathrm{pH}$ can be used to control sulphate reduction for anaerobic processes. Calcium, aluminium and sulphate react to form ettringite, according to Eq. (1):

$$
\begin{gathered}
6 \mathrm{Ca}^{2+}+3 \mathrm{SO}_{4}^{2-}+2 \mathrm{Al}(\mathrm{OH})_{4}^{-}+4 \mathrm{OH}^{-}+26 \mathrm{H}_{2} \mathrm{O} \rightarrow \\
3 \mathrm{CaO} \cdot \mathrm{Al}_{2} \mathrm{O}_{3} \cdot 3 \mathrm{CaSO}_{4} \cdot 32 \mathrm{H}_{2} \mathrm{O}_{(\mathrm{s})}
\end{gathered}
$$

Response surface methodology (RSM) is a mathematical and statistical technique that is useful for the optimization of chemical

Received November 15, 2017 Accepted May 7, 2018

${ }^{\dagger}$ Corresponding author

Email: ahmet.aygun@btu.edu.tr

Tel: +90-224-300-3590 Fax: +90-224-300-3419

ORCID: 0000-0002-6321-0350 
reactions such as ettringite crystallization. RSM is used in the development of an adequate functional relationship between a response of interest, and a number of associated control (or input) variables with limited number of experimental run. RSM designs offer ease of implementation and good performance over a wide range of applications [17-19]. RSM is a viable statistical method to optimize the treatment of industrial wastewaters [20, 21].

The purpose of this study is to investigate optimum conditions (important process variables such as $\mathrm{Ca} / \mathrm{SO}_{4}$ and $\mathrm{Al} / \mathrm{SO}_{4}$ molar ratios, and $\mathrm{pH}$ ) for high sulphate removal efficiency $\left(\mathrm{SO}_{4}{ }^{-2} \mathrm{RE}\right.$, $\%)$ with low operating cost (OC) $\left(\$ / \mathrm{m}^{3}\right)$ by crystallization. The central composite design (CCD) was selected in this study because of its efficiency with respect to the number of runs required for fitting a second order response surface model [22]. And also, crystallinity, surface structure and other microscopic characteristics of sludge are characterized by scanning electron microscope (SEM) and energy dispersive X-Ray spectroscopy (SEM-EDX).

\section{Materials and Methods}

\subsection{Chemical Composition of Landfill Leachates}

Leachate samples were collected from the active detention pond which is less than 5 years old (classified as young landfill leachate) in municipal landfill site of Konya. The characteristics of studied

Table 1. Characterization of Raw Leachate

\begin{tabular}{lc}
\hline Parameter & Value \\
\hline $\mathrm{pH}$ & 7.53 \\
$\mathrm{EC}(\mathrm{mS} / \mathrm{cm})$ & 18.6 \\
$\mathrm{COD}(\mathrm{mg} / \mathrm{L})$ & 17,280 \\
$\mathrm{BOD}(\mathrm{mg} / \mathrm{L})$ & 12,600 \\
$\mathrm{Alkalinity}\left(\mathrm{mg} \mathrm{CaCO}_{3} / \mathrm{L}\right)$ & 2,650 \\
$\mathrm{SO}_{4}(\mathrm{mg} / \mathrm{L})$ & 1,081 \\
$\mathrm{NH}_{3}(\mathrm{mg} / \mathrm{L})$ & 2,440 \\
$\left.\mathrm{TKN}_{\mathrm{mg}} / \mathrm{L}\right)$ & 2,642 \\
$\mathrm{PO}_{4}-\mathrm{P}(\mathrm{mg} / \mathrm{L})$ & 10.8 \\
$\mathrm{H}_{2} \mathrm{~S}(\mathrm{mg} / \mathrm{L})$ & 30.1 \\
$\mathrm{Mg}(\mathrm{mg} / \mathrm{L})$ & 362 \\
$\mathrm{Ca}(\mathrm{mg} / \mathrm{L})$ & 288 \\
$\mathrm{Al}(\mathrm{mg} / \mathrm{L})$ & 1.72 \\
$\mathrm{Na}(\mathrm{mg} / \mathrm{L})$ & 8,040 \\
$\mathrm{~K}(\mathrm{mg} / \mathrm{L})$ & 4,120 \\
$\mathrm{Cr}(\mathrm{mg} / \mathrm{L})$ & 1.97 \\
$\mathrm{Ni}(\mathrm{mg} / \mathrm{L})$ & 1.22 \\
$\mathrm{Cu}(\mathrm{mg} / \mathrm{L})$ & 0.22 \\
$\mathrm{Cd}(\mathrm{mg} / \mathrm{L})$ & 0.005 \\
$\mathrm{~Pb}(\mathrm{mg} / \mathrm{L})$ & 0.41 \\
\hline
\end{tabular}

landfill leachate are shown in Table 1.

Batch experiments were conducted in jar test apparatus for following minutes and rpms; $5 \mathrm{~min}$ at $120 \mathrm{rpm}, 20 \mathrm{~min}$ at 45 $\mathrm{rpm}$ and finally $30 \mathrm{~min}$ for settling. Aluminum chloride $\left(\mathrm{AlCI}_{3}\right)$ and calcium chloride $\left(\mathrm{CaCl}_{2}\right)$ are used as the source of mineral formation and $\mathrm{pH}$ was adjusted with either $6 \mathrm{M} \mathrm{HCl}$ or $\mathrm{NaOH}$.

\subsection{Experimental Design and Data Analysis}

The CCD was created using Design Expert software (version 11.0.3, Statease Inc., USA). In this study, three important process variables, namely $\mathrm{pH}$ and molar ratios of $\mathrm{Ca} / \mathrm{SO}_{4}$ and $\mathrm{Al} / \mathrm{SO}_{4}$ were considered in the planning. CCD was applied for experimental studies augmented with six central replicates. In order to obtain optimum $\mathrm{SO}_{4}^{-2} \mathrm{RE}(\%)$ was selected as the process response. The experimental ranges and levels of the independent variables used in RSM are given in Table 2, where a was set as 1.5 to determine second-order experimental points.

Independent variables and their levels for CCD and experimental results are given in Table 3. RSM postulates the functional relationship between the controllable input parameters and the obtained response surfaces [23, 24]. Response plots were generated using experimental data and the quality of the fitted polynomial model was expressed by the coefficient of determination $\mathrm{R}^{2}$ and its statistical significance was checked by Fisher's F-test value and following by statistical significant model $(p \leq 0.05)$ by using analysis of variance (ANOVA).

ANOVA was used for three-dimensional plots and respective contour plots to obtain the interaction between the process variables $\left(\mathrm{Ca} / \mathrm{SO}_{4}\right.$ and $\mathrm{Al} / \mathrm{SO}_{4}$ molar ratios and $\left.\mathrm{pH}\right)$ and the responses $\left(\mathrm{SO}_{4}{ }^{-2}\right.$ $\mathrm{RE}, \%$ and $\mathrm{OC}, \$ / \mathrm{m}^{3}$ ).

\subsection{Analytical Methods}

All chemicals used in this research were in analytical grade and supplied by Merck. COD, $\mathrm{BOD}_{5}$, Sulphate, Phosphate-phosphorus, Ammonium-nitrogen and $\mathrm{pH}$ were analyzed based upon Standard Methods [25]. Heavy metals were determined using the EPA 200.7 method of acid digestion followed by analysis by inductively coupled plasma with atomic emission spectroscopy (Optima 4300DV ICP, Perkin-Elmer, Boston, MA).

\subsection{Scanning Electron Microscope (SEM)}

SEM was performed using Evo LS10 (Carl Zeiss Microscopy $\mathrm{GmbH}$ ) scanning microscope equipped with an energy dispersive X-Ray spectroscopy (EDX) Bruker EDX detector. The SEM images were recorded at $10 \mathrm{kV}$. The fractured sample was attached to a metal mount and sputter-coated with gold-platinum by using a sputtering machine (Cressington 108 auto, Cressington, UK).

Table 2. Experimental Range and Levels of the Independent Variables Used in RSM

\begin{tabular}{lccccc}
\hline \multirow{2}{*}{ Independent process variables code } & \multicolumn{4}{c}{ Real values of coded levels } \\
\cline { 2 - 6 } & $\mathbf{- 1 . 5}$ & $\mathbf{- 1}$ & $\mathbf{0}$ & $\mathbf{1}$ & 12 \\
$\mathrm{pH}$ & 9.5 & 10 & 11 & 1.5 & 12.5 \\
$\mathrm{Ca} / \mathrm{SO}_{4}$ molar rates & 0.5 & 1.0 & 2.0 & 3.0 & 3.5 \\
$\mathrm{Al} / \mathrm{SO}_{4}$ molar rates & 0.17 & 0.33 & 0.66 & 0.99 & 1.16 \\
\hline
\end{tabular}


Table 3. The Actual Design Parameters of Ettringite Crystallization and Responses

\begin{tabular}{|c|c|c|c|c|c|}
\hline Exp No & $\mathrm{pH}\left(\mathrm{x}_{1}\right)$ & $\mathrm{Ca} / \mathrm{SO}_{4}\left(\mathrm{x}_{2}\right)$ & $\mathrm{Al} / \mathrm{SO}_{4}\left(\mathrm{x}_{3}\right)$ & $\mathrm{SO}_{4}^{-2} \mathrm{RE}(\%)$ & OC $\left(\$ / \mathbf{m}^{3}\right)$ \\
\hline 1 & 11 & 2.0 & 1.16 & 45.1 & 1.15 \\
\hline 2 & 11 & 0.5 & 0.66 & 45.2 & 0.66 \\
\hline 3 & 12 & 3.0 & 0.33 & 35.1 & 0.61 \\
\hline 4 & 11 & 2.0 & 0.66 & 65.5 & 0.66 \\
\hline 5 & 12 & 3.0 & 0.99 & 52.7 & 1.26 \\
\hline 6 & 10 & 1.0 & 0.33 & 34.3 & 0.47 \\
\hline 7 & 11 & 2.0 & 0.66 & 65.2 & 0.66 \\
\hline 8 & 11 & 2.0 & 0.66 & 65.4 & 0.66 \\
\hline 9 & 11 & 2.0 & 0.66 & 65.3 & 0.66 \\
\hline 10 & 11 & 2.0 & 0.17 & 35.2 & 0.17 \\
\hline 11 & 12.5 & 2.0 & 0.66 & 56.8 & 1.08 \\
\hline 12 & 11 & 2.0 & 0.66 & 65.3 & 0.66 \\
\hline 13 & 10 & 1.0 & 0.99 & 36.3 & 0.97 \\
\hline 14 & 11 & 3.5 & 0.66 & 51.8 & 0.92 \\
\hline 15 & 12 & 1.0 & 0.33 & 48.4 & 0.45 \\
\hline 16 & 9.5 & 2.0 & 0.66 & 37.8 & 0.64 \\
\hline 17 & 11 & 2.0 & 0.66 & 65.4 & 0.66 \\
\hline 18 & 12 & 1.0 & 0.99 & 47.2 & 1.11 \\
\hline 19 & 10 & 3.0 & 0.99 & 50.1 & 1.13 \\
\hline 20 & 10 & 3.0 & 0.33 & 36.2 & 0.32 \\
\hline
\end{tabular}

\section{Results and Discussion}

\subsection{Statistical Analysis}

In recent years, statistical methods such as RSM, have been used to model, identify, analyze and establish the relationship of input and output process parameters. The traditional optimization approaches can only estimate the main process parameter effects and are not sufficient to express the interaction factor effects with minimum number of experiments and computational burden [26]. Therefore, process variables need to be varied simultaneously to estimate the contribution of interaction effects. In the present work, the relationship between the three appropriate process variables $\left(\mathrm{pH}\right.$, molar ratios of $\mathrm{Ca} / \mathrm{SO}_{4}$ and $\mathrm{Al} / \mathrm{SO}_{4}$ ) and the effects on the predicted responses (sulphate RE (\%) and OC) was studied. The experimental data was analyzed by using the RSM procedure. CCD allows the development of second order quadratic regression models where each process response is assessed as a function of the process variables. The obtained results were then analyzed by ANOVA to examine the adequacy, correctness, and fitness of the obtained polynomial expressions.
The second-order quadratic polynomial model for $\mathrm{SO}_{4}^{-2} \mathrm{RE}$, \% were subjected to the F-test to judge their relative significance.

The final mathematical model equation (Eq. (2)) was obtained by dropping insignificant model term using backward elimination procedure as following for in terms of actual factors:

$$
\begin{aligned}
& \mathrm{SO}_{4}^{-2} \mathrm{RE}(\%)=-947.48+162.68 \mathrm{X}_{1}+51.64 \mathrm{X}_{2}+110.67 \mathrm{X}_{3} \\
& \quad-2.94 \mathrm{X}_{1} \mathrm{X}_{2}+11.63 \mathrm{X}_{2} \mathrm{X}_{3}-6.93 \mathrm{X}_{1}{ }^{2}-6.39 \mathrm{X}_{2}{ }^{2}-92.80 \mathrm{X}_{3}(2)
\end{aligned}
$$

The statistical parameters obtained from ANOVA for the established second-order quadratic polynomial regression model on the basis of the $\mathrm{SO}_{4}^{-2} \mathrm{RE}(\%)$ are shown in Table 4 .

In the present work, the proposed models to predict sulphate removal efficiency and treatment cost were significant at the $5 \%$ confidence level since $p$ value was less than 0.05 and both $\mathrm{R}^{2}$ and adjusted $\mathrm{R}^{2}$ coefficients ensured a satisfactory adjustment of the quadratic model to the experimental data [27]. A high $\mathrm{R}^{2}$ coefficient is desirable and it expresses a good fit for the second order quadratic model to the experimental data [28, 29].

The variance coefficient $(\mathrm{CV})$ is a measure of the model's

Table 4. ANOVA Results for Responses

\begin{tabular}{lccccccc}
\hline \multicolumn{1}{c}{ Response } & $\boldsymbol{p}$ Value $>\boldsymbol{F}$ & $\mathbf{R}^{2}$ & Adj. $\boldsymbol{R}^{\mathbf{2}}$ & Pred. $\mathbf{R}^{\mathbf{2}}$ & S.D. & CV & AP \\
\hline $\mathrm{SO}_{4}^{-2} \mathrm{RE}(\%)$ & $<0.0001$ & 0.973 & 0.954 & 0.857 & 2.57 & 5.12 & 18.7 \\
\hline $\mathrm{OC}\left(\$ / \mathrm{m}^{3}\right)$ & $<0.0001$ & 0.977 & 0.964 & 0.886 & 0.06 & 7.55 & 33.2 \\
\hline
\end{tabular}


reproducibility and, when its value is less than $10 \%$, the model can be considered as reasonably reproducible [30]. The adequate precision (AP) value is a measure of the 'signal-to-noise ratio' and was found as 18.7 , indicating an adequate signal, because a value $>4$ is desirable to use a regression model to navigate the space as defined by CCD [31, 32]. All other coefficients established by ANOVA postulate that the established regression model is significant and describe $\mathrm{SO}_{4}{ }^{-2} \mathrm{RE}$ (\%) satisfactorily.

Actual values were the result of an experimental run; however, the predicted values were determined from the model using the approximating functions. The data points of the actual response lie close to the predicted response as $\mathrm{SO}_{4}{ }^{-2} \mathrm{RE}, \%$ (Fig. 1).

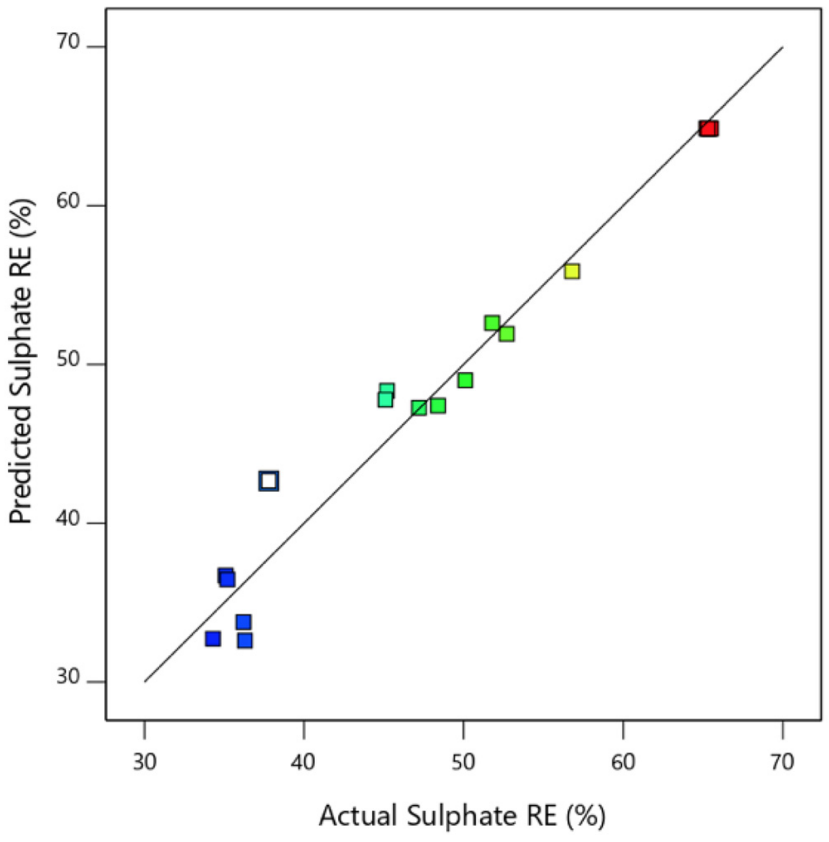

Fig. 1. The actual versus the predicted sulfate removal efficiency.

\subsection{Effect of Variables on the Sulphate Removal Efficiency}

In order to gain a better understanding of the obtained results, the second order quadratic model was presented as 3D response surface contour plots in Fig. 2-4 on the basis of sulphate removal efficiency and treatment cost.

The RSM plots presented in Fig. 2-4 exhibit a curvature more or less noticeable depending on the significances of the interaction and quadratic model terms. Although some saddle points were observed, no true maximum points (for $\mathrm{SO}_{4}^{-2} \mathrm{RE}$ ) and minimum points (for OC) could be detected on these plots, indicating that maximum $\mathrm{SO}_{4}^{-2} \mathrm{RE}(\%)$ and minimum OC $\left(\$ / \mathrm{m}^{3}\right)$ targets must be searched on the boundaries of the design space determined by experimental ranges of the process variables.

It is clearly seen that from the Fig. 2-4, the effects of $\mathrm{Ca} / \mathrm{SO}_{4}$ and $\mathrm{Al} / \mathrm{SO}_{4}$ molar ratios and $\mathrm{pH}$ were significant on sulphate removal efficiency. Sulphate removal efficiency sharply decreased at either highest or lowest molar ratios of $\mathrm{Ca} / \mathrm{SO}_{4}$ and $\mathrm{Al} / \mathrm{SO}_{4}$ values (Fig. 2).

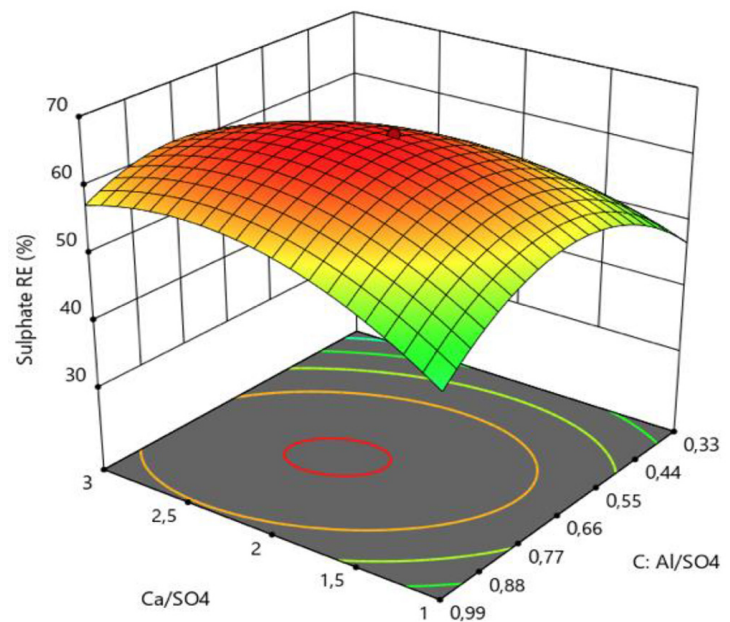

Fig. 2. The effect of $\mathrm{Ca} / \mathrm{SO}_{4}$ and $\mathrm{Al} / \mathrm{SO}_{4}$ molar ratios on sulphate removal efficiency ( $\mathrm{pH}:$ 11.00).

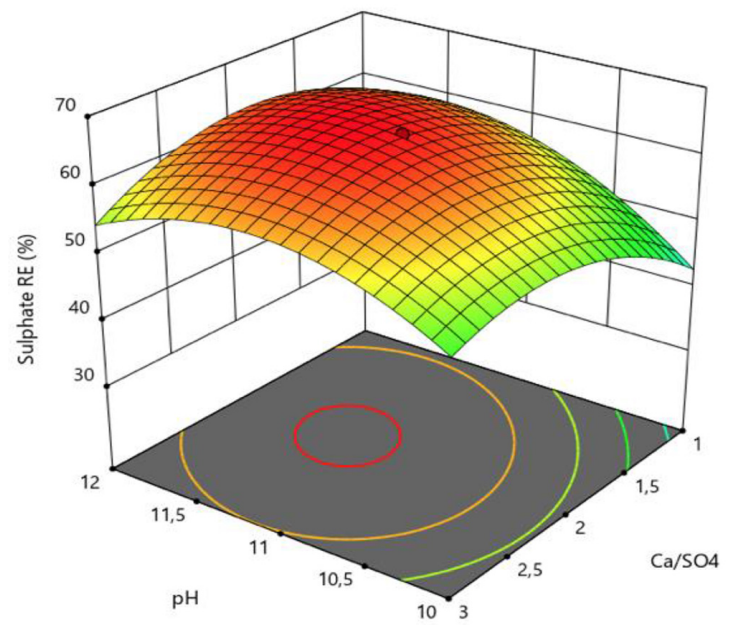

Fig. 3. The effect of $\mathrm{Ca} / \mathrm{SO}_{4}$ molar ratio and $\mathrm{pH}$ on sulphate removal efficiency $\left(\mathrm{Al} / \mathrm{SO}_{4}: 0.66\right)$.

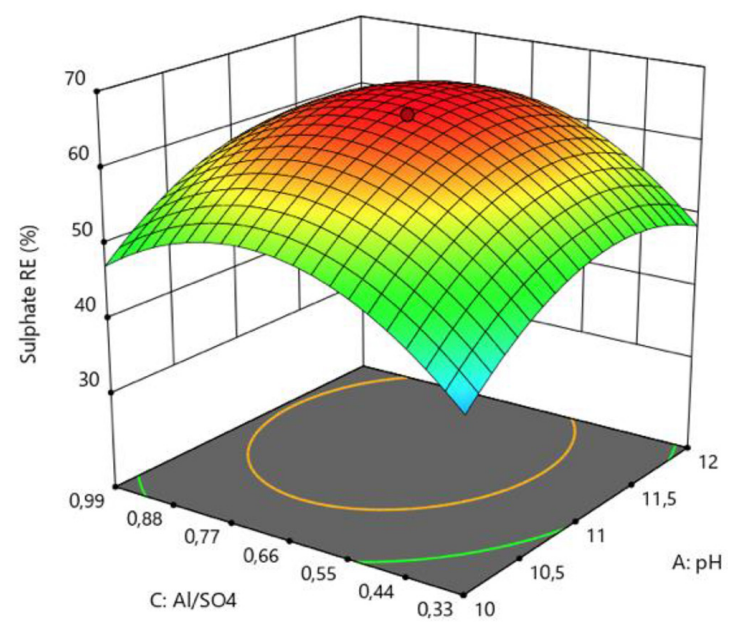

Fig. 4. The effect of $\mathrm{Al} / \mathrm{SO}_{4}$ molar ratio and $\mathrm{pH}$ on sulphate removal efficiency $\left(\mathrm{Ca} / \mathrm{SO}_{4}: 2.00\right)$. 
The effects of $\mathrm{pH}$ on sulphate removal efficiency is more influential comparing to $\mathrm{Ca} / \mathrm{SO}_{4}$ molar ratio changes (Fig. 3). Higher $\mathrm{pH}$ values and $\mathrm{Al} / \mathrm{SO}_{4}$ ratios increased the sulphate removal efficiency (Fig. 4). Ettringite mineral is a stable above a $\mathrm{pH}$ of 10.7 and up to a $\mathrm{pH}$ of 12.5. Increasing the upper limit of $\mathrm{pH}$ at which ettringite is stable, ettringite is converted to calcium hydroxide, leaving sulphate and aluminate ions [33, 34].

\subsection{Optimization Results}

Numerical optimization was used to find the best solution by using design expert software. The maximum sulphate removal efficiency and minimum OC $\left(\$ / \mathrm{m}^{3}\right)$ were considered to be two important goals in this study for the treatment of landfill leachate by the ettringite crystallization process. The corresponding importance of goals was selected as three out of five for all input variables and responses. The sulphate removal efficiency was estimated as $61.6 \%$ at $\mathrm{pH} 11.06,1.87$ of $\mathrm{Ca} / \mathrm{SO}_{4}$ and 0.51 of $\mathrm{Al} / \mathrm{SO}_{4}$ molar ratios with $0.52 \$ / \mathrm{m}^{3}$ OC.

The desirability value was 0.77 , showing that our model could be successfully applied to experimental data. The researchers have found different optimum conditions to form ettringite minerals in previous studies [35-37]. This is reveal that the composition of wastewater had an effect on stoichiometric ratio of each reagents and operating $\mathrm{pH}$.

At the optimum condition, sulphate concentration decreased from $1,081 \mathrm{mg} / \mathrm{L}$ to $415 \mathrm{mg} / \mathrm{L}$, but COD removal efficiency was only around $20 \%$. Ettringite precipitation increased the ratio of $\mathrm{COD} / \mathrm{SO}_{4}$ from $16: 1$ to $33: 1$ which was above the required ratio $\left(\mathrm{COD} / \mathrm{SO}_{4}>20\right)[16]$.

\subsection{Application of SEM-EDX for Microstructural Analysis of the Solidified/Stabilized Chemical Sludge}

The microstructural studies of solidified/stabilized chemical sludge were conducted using SEM and SEM-EDX tests. As shown in Fig. 5, tricalcium aluminate and also, need-like microstructure of ettringite, a hydration by-product of tricalcium aluminate in the presence of sulfate ions were detected. Ettringite is a stable hydration product only while there is an ample supply of sulfate available [38].

EDX analysis shows that the principle elements present in a micron volume region are oxygen, calcium and sodium. Chemical composition of sludge is given in Table 5 .

The presence of these elements and their distribution suggest that oxygen, the element most commonly found in the structure of the precipitate, is $65.98 \%$ in composition, calcium stems from the chemical substance added to precipitate, sodium comes from $\mathrm{pH}$ adjustment and due to the precipitated organic matter and carbonate minerals, the carbon atom is also observed at a relatively high rate. A minor amount of phosphorus, iron and silica ions is also visible for this study.

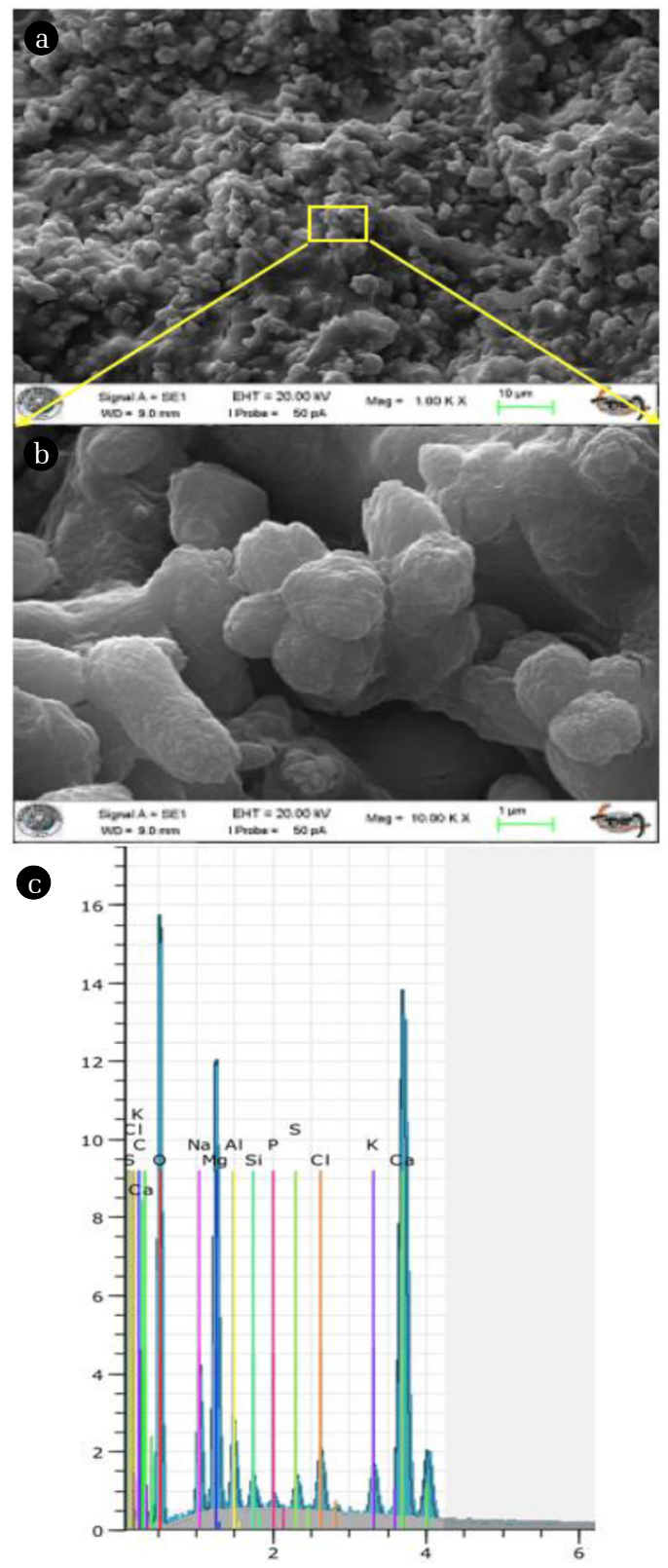

Fig. 5. Scanning Electron Micrograph (SEM) of chemical sludge for Run 8 a) $1 \mathrm{kx}$ b) $10 \mathrm{kx} \mathrm{c)}$ EDX spectrum.

\section{Conclusions}

The optimum levels of $\mathrm{Ca} / \mathrm{SO}_{4}$ and $\mathrm{Al} / \mathrm{SO}_{4}$ molar ratios and $\mathrm{pH}$ variables were investigated by CCD and RSM in this study. Second

Table 5. Chemical Composition of Sludge

\begin{tabular}{|c|c|c|c|c|c|c|c|c|c|c|c|}
\hline \multirow{2}{*}{ Sample } & \multicolumn{11}{|c|}{ Atomic (\%) } \\
\hline & $\mathbf{O}$ & Ca & Mg & C & $\mathrm{Na}$ & Al & $\mathbf{S}$ & Cl & $\mathbf{S i}$ & K & $\mathbf{P}$ \\
\hline Run 8 & 65.98 & 8.45 & 7.99 & 9.96 & 3.82 & 1.39 & 0.40 & 0.74 & 0.41 & 0.65 & 0.21 \\
\hline
\end{tabular}


order quadratic regression models were developed for the responses $\left(\mathrm{SO}_{4}^{-2} \mathrm{RE}, \%\right.$ and $\left.\mathrm{OC}, \$ / \mathrm{m}^{3}\right)$. The present study clearly showed that CCD was a suitable method to optimize ettringite crystallization process by maximizing the $\mathrm{SO}_{4}^{-2} \mathrm{RE}(\%)$ and minimizing the OC. The experimental data and model predictions were in good agreement. ANOVA resulted in high coefficients revealing that the proposed models were adequate and can be used to navigate the design space. At the optimum condition, $\mathrm{COD} / \mathrm{SO}_{4}$ ratio increased from 16:1 to $33: 1$ resulted in less sulphate inhibition on anaerobic methane production. The ettringite crystallization process seems to be a very appropriate method for achieving the highest $\mathrm{SO}_{4}^{-2} \mathrm{RE}(\%)$ and lowest $\mathrm{OC}$ for landfill leachate.

\section{Acknowledgments}

This study was funded by the The Scientific and Technological Research Council of Turkey, TUBITAK (Grant No.: 115Y031).

\section{References}

1. Renou S, Givaudan JG, Poulain S, Dirassouyan F, Moulin P. Landfill leachate treatment: Review and opportunity. J. Hazard. Mater. 2008;150:468-493.

2. Talalaj IA. Mineral and organic compounds in leachate from landfill with concentrate recirculation. Environ. Sci. Pollut. Res. 2015;22:2622-2633.

3. De Morais JL, Zamora PP. Use of advanced oxidation processes to improve the biodegradability of mature landfill leachates. J. Hazard. Mater. 2005;123:181-186.

4. Sari H, Yetilmezsoy K, Ilhan F, Yazici S, Kurt U, Apaydin O. Fuzzy-logic modeling of Fenton's strong chemical oxidation process treating three types of landfill leachates. Environ. Sci. Pollut. Res. 2013;20:4235-4253.

5. Agdag ON, Sponza DT. Anaerobic/aerobic treatment of municipal landfill leachate in sequential two-stage up-flow anaerobic sludge blanket reactor (UASB)/completely stirred tank reactor (CSTR) systems. Process Biochem. 2005;40:895-902.

6. Aygun A, Yilmaz T, Nas B, Berktay A. Effect of temperature on fenton oxidation of young landfill leachate: Kinetic assessment and sludge properties. Glob. Nest J. 2012;14:487-495.

7. Derco J, Gotvajn AZ, Zagorc-Končan J, Almásiová B, Kassai A. Pretreatment of landfill leachate by chemical oxidation processes. Chem. Pap. 2010;64:237-245.

8. Ilhan F, Kurt U, Apaydin O, Gonullu MT. Treatment of leachate by electrocoagulation using aluminum and iron electrodes. J. Hazard. Mater. 2008;154:381-389.

9. Trebouet D, Schlumpf JP, Jaouen P, Quemeneur F. Stabilized landfill leachate treatment by combined physicochemicalnanofiltration processes. Water Res. 2001;35:2935-2942.

10. Yilmaz T, Aygun A, Berktay A, Nas B. Removal of COD and colour from young municipal landfill leachate by Fenton process. Environ. Technol. 2010;31:1635-1640.

11. Abu Amr SS, Aziz HA, Hossain MS, Bashir MJK. Simultaneous removal of COD and color from municipal landfill leachate using Ozone/Zinc sulphate oxidation process. Glob. Nest J.
2017;19:498-504.

12. Sahinkaya E, Gunes FM, Ucar D, Kaksonen AH. Sulfidogenic fluidized bed treatment of real acid mine drainage water. Bioresour. Technol. 2011;102:683-689.

13. Liu Y, Zhang Y, Ni BJ. Zero valent iron simultaneously enhances methane production and sulfate reduction in anaerobic granular sludge reactors. Water Res. 2015;75:292-300.

14. Zub S, Kurissoo T, Menert A, Blonskaja V. Combined biological treatment of high-sulphate wastewater from yeast production. Water Environ. J. 2008;22:274-286.

15. Wang Z, Banks CJ. Treatment of a high-strength sulphate-rich alkaline leachate using an anaerobic filter. Waste Manage. 2007;27:359-366.

16. Yilmaz T, Erdirencelebi D, Berktay A. Effect of $\mathrm{COD} / \mathrm{SO}_{4}{ }^{2-}$ ratio on anaerobic treatment of landfill leachate during the start-up period. Environ. Technol. 2012;33:313-320.

17. Sudamalla P, Pichiah S, Manickam M. Responses of surface modeling and optimization of Brilliant Green adsorption by adsorbent prepared from Citrus limetta peel. Desalin. Water Treat. 2012;50:367-375.

18. Hay JXW, Wu TY, Teh CY, Jahim JM. Optimized growth of Rhodobacter sphaeroides O.U.001 using response surface methodology (RSM). J. Sci. Ind. Res. 2012;71:149-154.

19. Shak KPY, Wu TY. Optimized use of alum together with unmodified Cassia obtusifolia seed gum as a coagulant aid in treatment of palm oil mill effluent under natural $\mathrm{pH}$ of wastewater. Ind. Crops Prod. 2015;76:1169-1178.

20. Zodi S, Potier O, Lapicque F, Leclerc JP. Treatment of the industrial wastewaters by electrocoagulation: Optimization of coupled electrochemical and sedimentation processes. Desalination 2010;261:186-190.

21. Guvenc SY, Erkan HS, Varank G, Bilgili MS, Engin GO. Optimization of paper mill industry wastewater treatment by electrocoagulation and electro-Fenton processes using response surface methodology. Water Sci. Technol. 2017;76:2015-2031.

22. Subramonian W, Wu TY, Chai SP. An application of response surface methodology for optimizing coagulation process of raw industrial effluent using Cassia obtusifolia seed gum together with alum. Ind. Crops Prod. 2015;70:107-115.

23. Li H, Zhou S, Sun Y, Lv J. Application of response surface methodology to the advanced treatment of biologically stabilized landfill leachate using Fenton's reagent. Waste Manage. 2010;30:2122-2129.

24. Subramaniam R, Gang DD, Nie J, et al. Application of response surface methodology for optimization of treatment for an aged landfill leachate using fenton's oxidation reagent. Environ. Eng. Sci. 2017;34:731-739.

25. Standard methods for the examination of water and wastewater. 22nd ed. In: Rice EW, Baird RB, Eaton AD, Clesceri LS, eds. American Public Health Association, American Water Works Association, Water Environment Federation. 2012. p. 741.

26. Ozer A, Gurbuz G, Calimli A, Korbahti BK. Biosorption of copper(II) ions on Enteromorpha prolifera: Application of response surface methodology (RSM). Chem. Eng. J. 2009;146: 377-387.

27. Korbahti BK, Tanyolac A. Electrochemical treatment of simulated textile wastewater with industrial components and 
Levafix Blue CA reactive dye: Optimization through response surface methodology. J. Hazard. Mater. 2008;151:422-431.

28. Ghafari S, Aziz HA, Isa MH, Zinatizadeh AA. Application of response surface methodology (RSM) to optimize coagulation-flocculation treatment of leachate using poly-aluminum chloride (PAC) and alum. J. Hazard. Mater. 2009;163:650-656.

29. Arslan-alaton I, Kobya M, Akyol A, Bayramoglu M. Electrocoagulation of azo dye production wastewater with iron electrodes: Process evaluation by multi-response central composite design. Color. Technol. 2009;125:234-241.

30. Yusuf F, Chaubey A, Raina A, Jamwal U, Parshad R. Enhancing nitrilase production from Fusarium proliferatum using response surface methodology. Springerplus 2013;2:290.

31. Kobya M, Gengec E, Sensoy MT, Demirbas E. Treatment of textile dyeing wastewater by electrocoagulation using Fe and $\mathrm{Al}$ electrodes: Optimisation of operating parameters using central composite design. Color. Technol. 2014;130:226-235.

32. Rahbar RS, Haji A. Use of D-optimal design to model and the analysis of the effect of the draw ratio on some physical properties of hot multistage drawn nylon 6 fibers. J. Appl.
Polym. Sci. 2013;130:1337-1344.

33. Gabrisová A, Havlica J, Sahu S. Stability of calcium sulphoaluminate hydrates in water solutions with various $\mathrm{pH}$ values. Cement Concrete Res. 1991;21:1023-1027.

34. Álvarez-Ayuso E, Nugteren HW. Synthesis of ettringite: A way to deal with the acid wastewaters of aluminium anodising industry. Water Res. 2005;39:65-72.

35. Sapsford DJ, Tufvesson S. Properties of recycled sludge formed from different aluminiferous reagents during the ettringite process. J. Water Process Eng. 2017;19:305-311.

36. Dou W, Zhou Z, Jiang LM, et al. Sulfate removal from wastewater using ettringite precipitation: Magnesium ion inhibition and process optimization. J. Environ. Manage. 2017;196:518-526.

37. Kabdasli I, Bilgin A, Tunay O. Sulphate control by ettringite precipitation in textile industry wastewaters. Environ. Technol. 2016;37:446-451.

38. Konsta-Gdoutos MS, Shah SP. Hydration and properties of novel blended cements based on cement kiln dust and blast furnace slag. Cement Concrete Res. 2003;33:1269-1276. 